\title{
Impact of ground water level oscillations on lead concentration in the Jaworzno area
}

\author{
M. Gwozdziewicz, A. Bauerek \& Z. Bzowski \\ Central Mining Institute, Katowice, Poland
}

\begin{abstract}
This paper presents the results of lead content tests obtained during the underground and surface water monitoring in the area of municipal landfill in Jaworzno (Sląskie voivodship, Poland). The appearance of high lead contents in the specific monitoring points was related with environmental data, the geological structure of the area in question and geo-chemical properties of the water bearing Triassic rocks. The over tenfold increase of lead contents (in the range from $0,01 \mathrm{mg} / \mathrm{dm}^{3}$ to $0,1 \mathrm{mg} / \mathrm{dm}^{3}$ ) was correlated with the extremely low level of underground water. This paper takes into consideration the possibility of occurrence of naturally over-normative lead contents in underground water. Based upon the geo-chemical test results it was stated that the increased content of lead in underground water is probably related to oxidization of ore materials that appear naturally in Triassic dolomites and contain lead. These minerals, initially in the saturation zone, due to the lowering of underground water level were covered by the aeration zone and from being hardly soluble they migrated toward easily soluble. Such a sudden increase of lead contents until the standards for drinking water are exceeded may result in harmful effects for human health. Keywords: lead concentration, lead in underground water.
\end{abstract}

\section{Introduction}

Monitoring of underground water quality in the carbonate Triassic series within the area of municipal landfill in Jaworzno has been carried out in a continuous manner since June 2000. Water samples are taken, among others, from three piezometers prepared for determination of the impact of the municipal landfill on the quality of underground water. The researches cover with their scope a range of physico-chemical parameters, including lead contents. An increased content of 
several elements that have been noted (such as chromium or nitrogen) in underground water is without doubt related to the many years of long operation of the municipal landfill.

Storage of municipal waste in post-dolomite workings (Fig. 1) started in the second half of 1971. The monitoring of underground water in this landfill has been carried out since 2000, and the increased lead content was noted in the period 2003-2005. Several occurrences of high lead concentration in underground water is of particular importance for the safe operation of underground water drawing point "Dobra" (wells D1 and D2) located $1100 \mathrm{~m}$ from the landfill (Fig. 2).

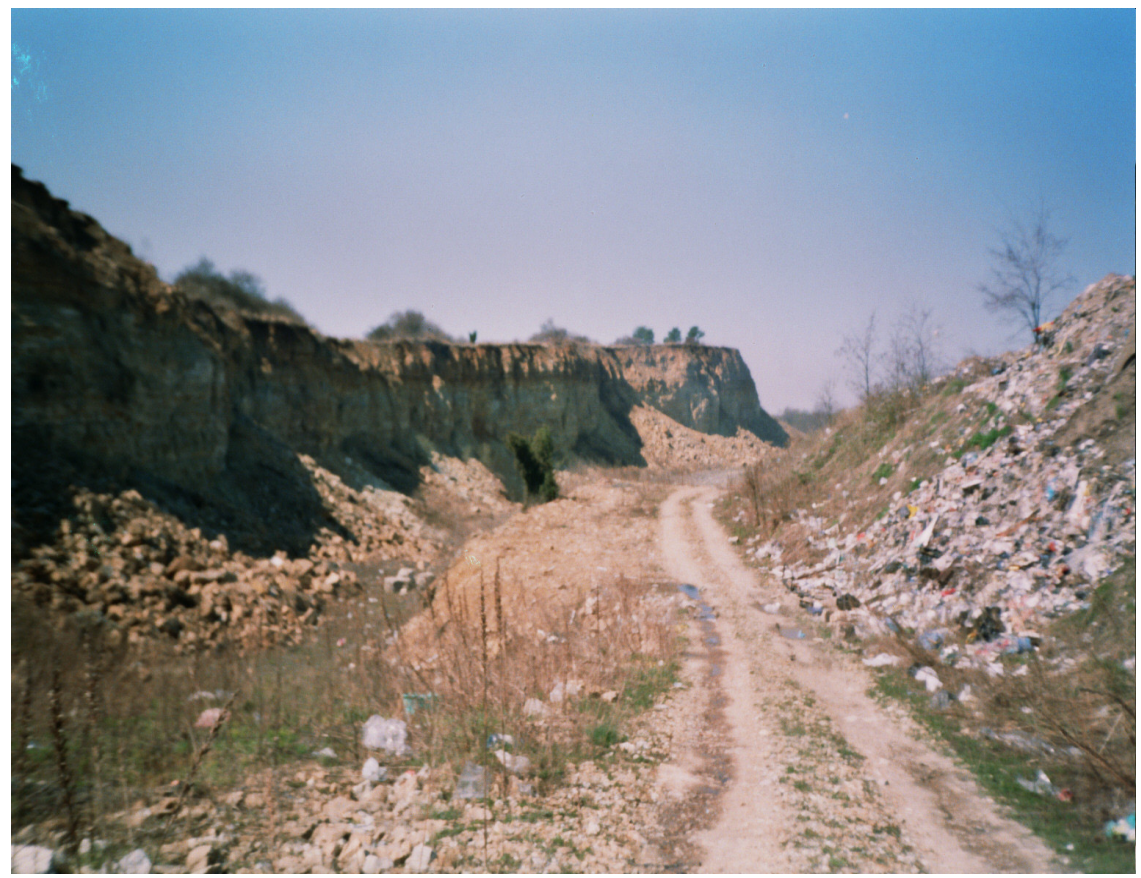

Figure 1: Post-dolomite workings of Grodek mine with municipal landfill visible to the right.

\section{Geological structure and hydro-geological conditions}

The area covered by the underground water monitoring is located in the northeastern part of Jaworzno (Pieczyska quarter). From a hydrological point of view this area lies within the watershed area of Luznik stream and Kozi Brod water course, being the right bank tributaries of Biala Przemsza River.

The area in question is located in the reach of the existing Triassic formation of Silesia and Cracov monocline, representing the fold and block tectonics in the northern area of Wilkoszynska basin. The geological profile of the area features Carbonaceous, Triassic and Quaternary formations. Carbonaceous formations are 
formed as a complex of detritus rocks of Cracovian sandstone series with thickness ca $300 \mathrm{~m}$. Carbonaceous rocks do not form outcrops.

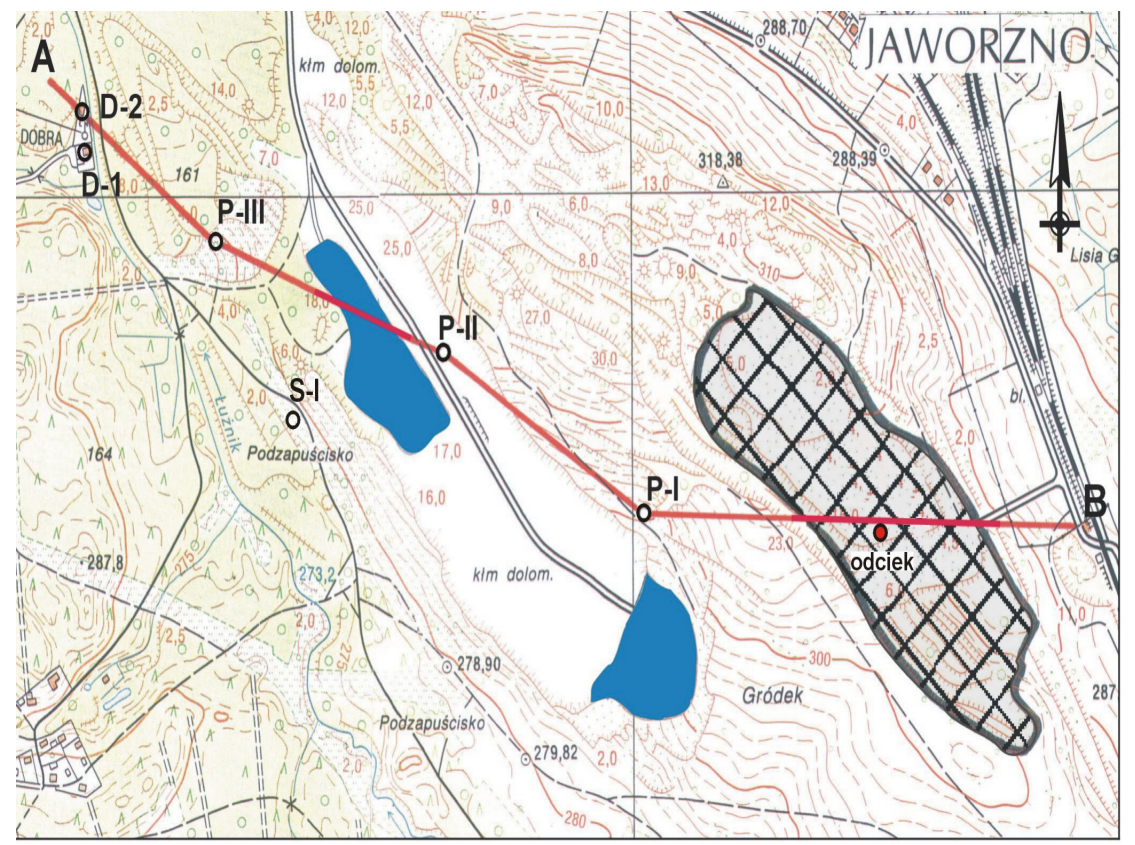

Figure 2: Location map of the underground water monitoring area in the vicinity of "Dobra" water drawing point in Jaworzno, with a geological cross-section line.

The lower Triassic deposits lying out of order on the Carbonaceous formations are formed as mud and sand of lower and middle sandstone $(5-10 \mathrm{~m}$ thick) as well as marls and ret dolomites (35 - $45 \mathrm{~m}$ thick). Above there are formations counted as bottom and middle shell limestone. These formations are represented by limestone, dolomites and marls of Gogolin strata, epigenetic (orebearing) dolomites created as a result of transformation of Gorazdze, Terebratula and Karchowice strata as well as diplopore dolomites. The tickness of these shell limestone deposits is the highest in the area of the "Dobra" drawing point where it is ca. $50 \mathrm{~m}$. East of the drawing point towards the landfill the thickness of Triassic deposits is lower (Fig. 3).

The described carbonate rocks of shell limestone and ret constitute a specific land culmination between the "Dobra" drawing point and landfill. In this area, in the past, a dolomite strip mine "Grodek" was in operation.

The appearance of Quaternary deposits in the area of the "Dobra" drawing point is restricted to the concave land forms. These deposits are Holocene residues, sands and gravels filling the Luznik stream valley. The tickness of Quaternary deposits in the discussed area does not exceed $10 \mathrm{~m}$. 


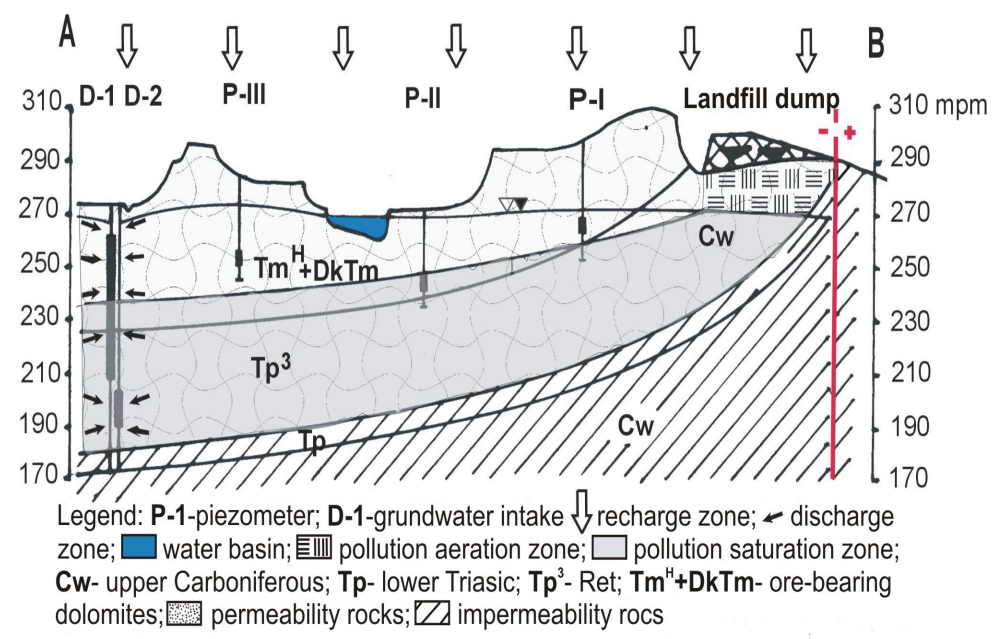

Figure 3: Hydrogeological cross-section with the presented direction of pollutant migration from the municipal landfill towards the potable water drawing point "Dobra".

In the hydrogeological approach, the area in question is located in the Silesia and Cracov region and Silesian Triassic subregion. Advantageous hydrogeological parameters of the reservoir rocks in the area of both the Dobra intake point in Jaworzno and the entire carbonate Triassic complex in the area of the Wilkoszynska and Chrzanowska Basin have prevailed on the decision of the location of the Chrzanow Main Reservoir of Underground Water in this area (T5).

The Quaternary water bearing level in the area in question is related to the appearance of Holocene and Pleistocene deposits filling the Biala Przemsza valley on the north east and Luznik stream valley in the eastern part. This level is fed with infiltration of atmospheric precipitations. Quaternary water bearing levels are of local meaning and are drawn only with household wells.

In the hydrogeological profile of this Triassic water bearing level of the "Dobra" water drawing point the following water strata exist:

- $\quad$ Shell limestone (middle Triassic),

- $\quad$ ret (bottom Triassic).

Water bearing strata of shell limestone and ret, built of limestone and dolomite, are of gap-karst-pore character. The above mentioned strata were primarily divided by marl formations of Gogolin strata. As a result of dolomitization and dislocation, these formations have lost, however, their isolating properties. Because of the above, the shell limestone and ret level is described as one water bearing complex called "water bearing complex of Triassic carbonate series". The water bearing stratum of Triassic carbonate series 
in the drawing point area is fed with infiltration of atmospheric precipitations into the broken carbonate rocks and watered Quaternary deposits. In the hydrogeological profile of "Dobra" water bearing strata of shell limestone and ret appear in the hydraulic bond. Well D-1 uses the a/m strata jointly (non-piped hole below 11,6 m), draining mainly shell limestone formations. Well D-2, with a filter built in at the level from $71,0 \mathrm{~m}$ to $88,0 \mathrm{~m}$ drains mainly the waterbearing strata of ret formations (Fig 3). Triassic water bearing rocks in the investigated area feature advantageous hydrogeological parameters expressed by filtration rations with values from $1,17 \times 10^{-4} \mathrm{~m} / \mathrm{s}$ to $3,07 \times 10^{-5} \mathrm{~m} / \mathrm{s}$. The vulnerability of water bearing stratum of Triassic carbonate series in the area under investigation to degradation is high. Lack of insulating deposits in the ceiling, large breaks in the rock mass and short times of vertical permeation (from several weeks to 2 years) result in the fact that the area of the "Dobra" drawing point may be deemed as very highly vulnerable to a possibility of contamination.

\section{Methods and scope of research}

Within the performed monitoring of municipal landfill in Jaworzno, the investigation of the chemical composition of underground water was carried out every month till the end of 2005. The broad range of physico-chemical analyses made on water samples taken included, among others, establishing heavy metal content, including chromium, zinc, cadmium, copper, nickel, lead and mercury. Concentrations of the above mentioned metals were established using a nuclear emission spectrometer with plasma excitation ICP-OES.

\section{Discussion of results}

The observed quality of underground water of the investigated area is influenced not only by depositionof municipal wastes (nitrogen compounds) in the former workings of the dolomite mine (Fig 1) but also actions related to illegal depositing of hazardous wastes (such as tanning wastes containing chromium compounds) in the past. The above actions have lead to contamination of the aeration zone under the landfill and penetration of chromium and nitrogen compounds to the underground water in the area of the "Dobra" water drawing point. The sudden increase of lead content that has been noted in the water samples tested in the range from characteristic values for the geo-chemical background $\left(<0,01 \mathrm{mg} / \mathrm{dm}^{3}\right)$ up to values of even $0,16 \mathrm{mg} / \mathrm{dm}^{3}$ was initially related with the impact of municipal landfill. Concentrations of this element in amounts of ca $0,06 \mathrm{mg} / \mathrm{dm}^{3}$ (both in underground water monitored by piezometers and surface reservoirs (Fig 4) created by flooding of existing workings) have started to appear at the lower levels of underground water. The dependence of growing lead content in water from the depth of underground water level is presented in Fig. 5 and 6. 


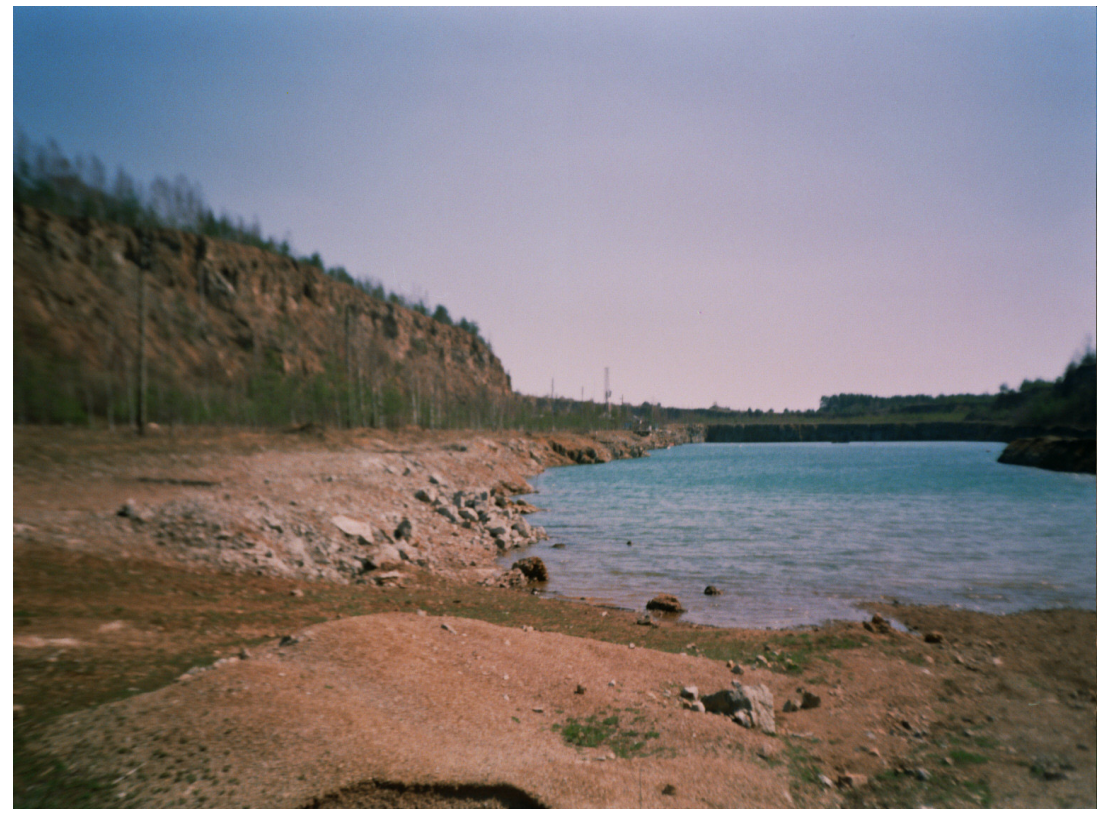

Figure 4: A flooded post-dolomite working (surface reservoir) of the closed down Grodek mine presently used for recreation and sport purposes.

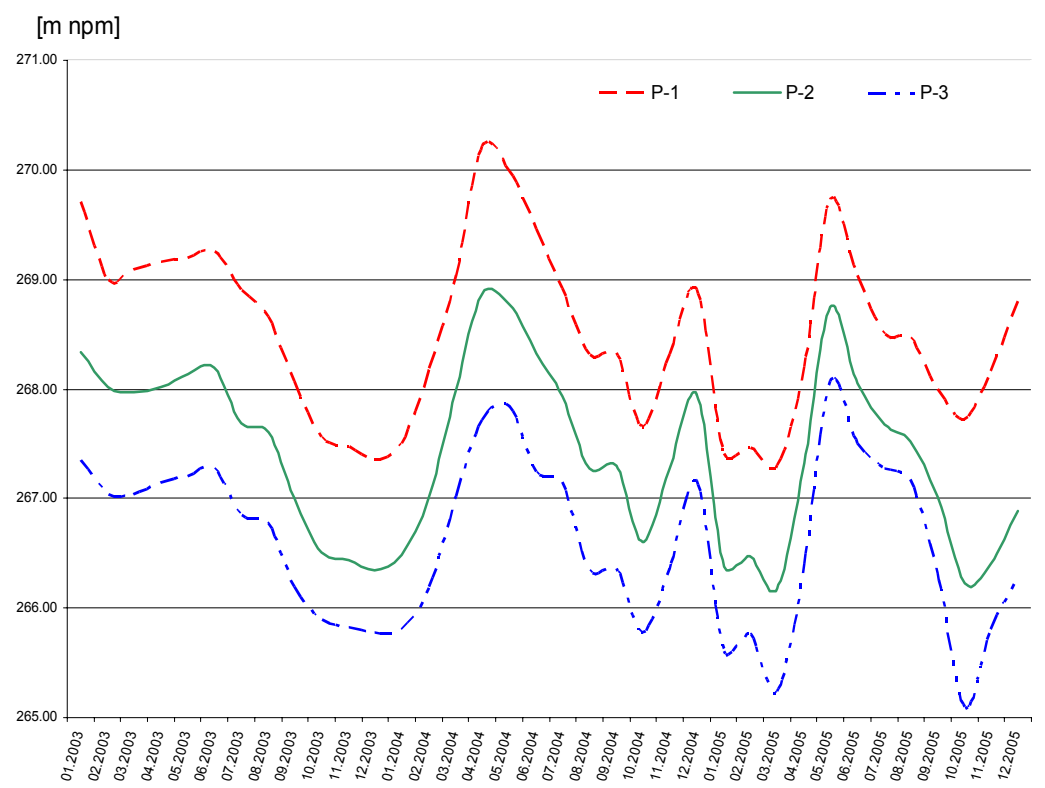

Figure 5: Oscillations of ordinates of underground water level in the monitored piezometers in the period 2003-2005. 


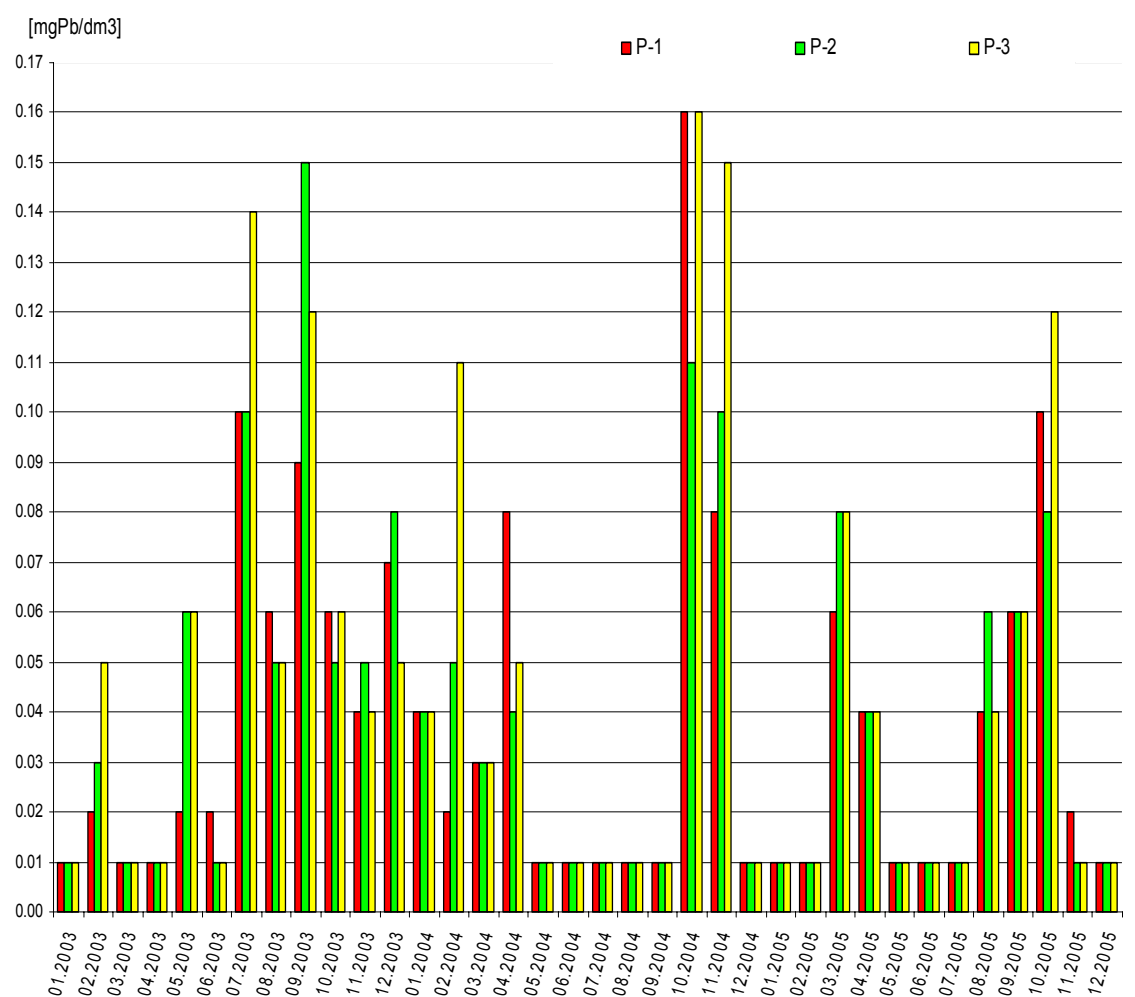

Figure 6: Lead contents in the samples of water taken from the monitored piezometers in the period 2003-2005.

However, such a raised concentration of lead was not observed in piezometer water and in the surface reservoir water (flooded mining workings) at the high levels of underground water.

The sudden occurrences of lead simultaneously at all monitoring points as well as the sudden drop of its content during the monitoring performed are caused by quasi-natural weathering factors.

Removal of the natural soil cover and weathered rock of dolomite rock mass as well as intense mining operations in the discussed area have resulted in a large exposition of dolomites containing ore mineralization. Strong weathering of rock and presence of pyrites or marcasite in the dolomites makes the galena (lead sulfite) decomposition process easier through iron sulfates and sulfuric acid created as a result of oxidization. Lead sulfate is relatively slowly moving and, because of this fact, its secondary concentration takes place at the boundary of the saturation and aeration zones. An apparent correlation between the seasonrelated changes of underground water level and lead concentration in the water samples tested is presented in Fig 5 and 6 . In the drawings presented, the growing tendencies of underground water during and after high and long term "downs" correspond to the growth of lead contents and - respectively - the full 
restoration of underground water level is correlated with decreasing lead content. The phenomenon observed is probably related to the intense washing of oxidized and secondarily concentrated lead compounds (probably mainly in the form of bicarbonates) during the growth of the water level. Washing out of lead compounds from the broadened and lead compound rich aeration level resulting from lowering of the ordinate of the underground water level is of two-factor character:

$>$ through well oxygen-permeated precipitation water infiltrating from the surface, with neutral or slightly acid $\mathrm{pH}$ reaction,

$>$ through intense washing of oxidization zone by flowing underground water caused by raising level of underground water.

The quality of results obtained is also highly influenced by the method of local monitoring network performance. Analysis of geological structure, hydrogeological situation and geo-chemistry of hydrogeological field of this area enabled determination of both the flow route of contaminated underground water (nitrogen and chromium compounds) and a description of the impact of natural geochemical processes on the quality of underground water (lead concentration). Water, contaminated by effluents, migrates in the floor part of the presented synclinal hydrogeological structure from the landfill to the potable water drawing point. The increased lead contents are noted simultaneously in all monitoring points during the significant lowering of theunderground water level and during its raising.

\section{Summary}

The purpose of research performed by the Environment Monitoring Department at GIG is recognition and control of Jaworzno municipal landfill impact on the quality of underground water in the north-eastern part of GZWP Chrzanow. The results obtained of lead content in piezometers and surface reservoirs were correlated with oscillation of the Triassic level of the underground water and a notable correlation between these factors was established. As a result of research performed, discrepancies were found between the character and way of appearance of various contaminants in underground water of the "Dobra" drawing point area. The monitoring performed has confirmed the relationship between the appearance of nitrogen and chromium compounds in underground water and operation of municipal landfill and has excluded the impact of the latter upon the high concentration of lead in the water. The established model of pollutants' migration has shown that the monitoring network did not fully reflect the real flow of pollutants in the Triassic water bearing level.

The observed improvement of monitored water quality is related to the considered careful landfill management in the last period, with slow return of greenery in the areas of the mine workings and advanced process of landfill reclamation. 


\section{References}

[1] Bauerek A., Gwozdziewicz M.: Migracja chromu w wodach podziemnych węglanowej serii Triasu rejonu ujęcia "Dobra" w Jaworznie.(Chromium migration in the underground water of carbonate Triassic series of "Dobra" drawing point area in Jaworzno) Zeszyty Naukowe Politechniki Śląskiej "Górnictwo" z. 256, Gliwice 2003.

[2] Bojarska K., Bzowski Z., Łabuz B.: Monitoring wód podziemnych w rejonie rekultywowanego składowiska odpadów komunalnych w Jaworznie. (Monitoring of underground water in the area of reclaimed municipal landfill in Jaworzno) Ekologia i Technika Vol. X, nr 4, 113- 122, Bydgoszcz 2002.

[3] Macioszczyk A.: Hydrogeochemia. (Hydro-geo-chemistry) Wydawnictwa Geologiczne, Warsaw 1987.

[4] Polański A., Smulikowski K.: Geochemia. (Geo-chemistry) Wydawnictwa Geologiczne, Warsaw 1969.

[5] Różkowski A.: Szczelinowo-krasowe zbiorniki wód podziemnych Monokliny Śląsko- Krakowskiej i problemy ich ochrony.(Crack and carse underground water reservoirs of Silesia and Cracov Monocline and their protection). Wyd. SGGW-AR, Warsaw 1990.

[6] Różkowski A., Chmura A., Siemiński A.: Użytkowe wody podziemne Górnośląskiego Zagłębia Węglowego i jego obrzeżenia. (Useful underground water of Ypper Silesia Coal Basin and its border) Reports of PIG CLIX Warsaw 1997.

[7] Stupnicka E.: Geologia regionalna Polski. (Regional Geology of Poland) Issue by UW Warsaw 1997.

[8] Szczepańska J., Kmiecik E.: Statystyczna kontrola jakości danych w monitoringu wód podziemnych. (Statistic control of data quality in the underground water monitoring) Issue by AGH Kraków 1998. 